\title{
SECTION 1981 AND DISCRIMINATION IN PRIVATE SCHOOLS
}

In McCrary v. Runyon ${ }^{1}$ the Court of Appeals for the Fourth Circuit became the first appellate court to extend the application of the Civil Rights Act of $1866^{2}$ to private schools. The court, sitting en banc, held four to three that the parents of a black child who was excluded from a private elementary school solely on the basis of his race were demied the "same right . . . to make and enforce contracts . . . as is enjoyed by white citizens"3, guaranteed by section 1981 .

The rise in the number of private scliools in the South can be directly linked to federal enforcement of racial integration in the public scliools. ${ }^{4}$ Although segregation was declared unconstitutional in 1954, it was not until after the enactment of the Civil Rights Act of $1964^{6}$ and the Supreme Court's 1968 decision in Green v. County School Board ${ }^{7}$

THE FOLLOWING CITATIONS WILL BE USED IN THIS NOTE:

Note, Desegregation of Private Schools: Section 1981 as an Alternative to State Action, 62 Geo. L.J. 1363 (1974) Thereinafter cited as Private Schools];

Note, The Desegregation of Private Schools: Is Section 1981 the Answer?, 48 N.Y.U.L. REv. 1147 (1973) [hereinafter cited as Is 1981 the Answer?];

Note, Section 1981 and Private Groups: The Right to Discriminate Versus Freedom from Discrimination, 84 YAIE L.J. 1441 (1975) [hereinafter cited as Private Groups];

Note, Segregation Academies and State Action, 82 YALE L.J. 1436 (1973) [hereinafter cited as Segregation Academies].

1. 515 F.2d 1082 (4th Cir. 1975) (en banc), aff'g sub nom. Gonzales v. FairfaxBrewster School, 363 F. Supp. 1200 (E.D. Va. 1973), cert. granted, 96 S. Ct. 354 (1975).

2. 42 U.S.C. $\S \S 1981$ et seq. (1970).

3. Id. $\$ 1981$.

4. Private Schools 1364; 151981 the Answer? 1148-49; Note, Post-Brown Private White Schools-An Imperfect Dualism, 26 VAND. L. REv. 587 (1973); Segregation Academies 1436; 7 LoYola OF L.A.L. Rev. 634 (1974).

5. Brown v. Board of Educ., 347 U.S. 483 (1954) (fourteenth amendment); Bolling v. Sharpe, 347 U.S. 497 (1954) (fifth amendment).

6. Pub. L. No. $88-352,78$ Stat. 241 (codified in various sections of $5,28 \& 42$ U.S.C.).

7. 391 U.S. 430 (1968). In Green the Court was confronted with a "Ireedomof-choice" plan for desegregating the public schools of New Kent County, Virginia. Students were allowed an annual choice as to which of the two available schools in the county they wished to attend. During the plan's three years of operation no white student had chosen to attend the all-black school, although 115 blacks were enrolled in the forinerly all-white school. The effect was that eighty-five percent of the black students in the system still attended the all-black school.

Justice Brennan made it clear that the Court's patience had worn thin: "[A] plan that at this late date fails to provide meaningful assurance of prompt and effective dis- 
that the growth of such schools became dramatic. ${ }^{8}$ Until the Fourth Circuit's decision in $\mathrm{McCrary}$, redress for discrimination by a private school in its admission policies could be had only after significant government involvement in the "segregation academy" could be shown. ${ }^{10} \mathrm{McC}$ rary, however, extends the judiciary's reach to purely

establishment of a dual system is also intolerable. "The time for mere "deliberate speed" has run out' . . . . The burden on a school board today is to come forward with a plan that promises realistically to work, and promises realistically to work now." Id. at 438-39 (emphasis in original), quoting Griffin v. County School Bd., 377 U.S. 218 (1964) and Brown v. Board of Educ., 349 U.S. 294 (1955) (Brown II).

The message apparently was received, because the level of integration achieved since Green has been substantial. From the 1965-66 school year to the 1972-73 school year, the percentage of Southern black students attending all-black schools dropped from 84.9 to 9.2 percent.

8. Estimated enrollment in Southern private schools, either begun or expanded in response to desegregation, increased from approximately 25,000 in 1966 to about 535,000 in 1972. Terjen, Close-up on Segregation Academies, New South 50 (Fall 1972), cited in Segregation Academies 1441. See also Segregation Academies 1442 n.45. The Wall Street Journal reportcd that total private school enrollment in the South went from 610,000 students to 859,000 students-a forty-one percent increase-in the four years after Green was decided (1968-1972). Wall Street J., Dec. 17, 1973, at 17, col. 3. It should be borue in mind that all such figures are very likely understated since reporting by private schools is voluntary in some states. See Segregation Academies $1442 \mathrm{n}, 45$.

9. A "segregation academy" has been defined as a private school "operated on a racially segregated basis as an alternative available to white students secking to avoid desegregated public schools." Coffey v. Educational Fin. Coinm'n, 296 F. Supp. 1389, 1392 (S.D. Miss. 1969). Of course, not every Southern private school is a "segregation academy." See generally Private Schools 1365 n.15; Segregation Academies 1443-44.

Perhaps the primary deleterious impact of segregation academies has been financial. Since state funding to the public schools is normally based on the average daily attendance, the desertion of the public facilities has also decreased funding. In addition, new bond issues have met increasing resistance at the polls, and less support for public education among legislatures and school boards has been observed. This is due at least in part to the fact that a sinaller percentage of the school-age population is now attending public schools. See generally Private Schools 1366; Segregation Academies 1452-53.

10. Since discrimination was found unconstitutional under the fourteenth amendment, Brown v. Board of Educ., 347 U.S. 483 (1954), state action had to be demonstrated. Such government involvement has been found when public resources are made available to private schools, either in the form of frce textbooks, Norwood v. Harrison, 413 U.S. 455 (1973), all school materials, Hall v. School Bd., 197 F. Supp. 649 (E.D. La. 1961), aff'd, 368 U.S. 515 (1962), or tuition grants, Poindexter v. Financial Assistance Coinm'n, 275 F. Supp. 833 (E.D. La. 1967), aff'd, 389 U.S. 571 (1968). See also Green v. Connally, 330 F. Supp. 1150 (D.D.C.), aff'd sub nom. Coit v. Green, 404 U.S. 997 (1971); Griffin v. County School Bd., 377 U.S. 218 (1964).

There is dictum advocating a liberalized state action approach in this area:

At the outset, one may question whether any school or college can ever be so "private" as to escape the reach of the Fourteenth Amendment. ... No one any longer doubts that education is a matter affected with the greatest public interest. And this is true whether it is offered by a public or private institution. ....

Reason and authority strongly suggest that the Constitution never sanctions racial discrimination in our schools and colleges, no matter how "private" 
private discrimination on the basis of race. The segregation academies are no longer immune. ${ }^{11}$

The serious implications of the issues at stake in McCrary have not gone urmoticed by the Supreme Court, which has granted certiorari. ${ }^{12}$ This Note will examine the Fourtl Circuit's reasoning in light of Supreme Court precedents and an analysis of section 1981 itself, and will explore the potential ramifications of the decision on this crucial question.

\section{Revival of the Civil Rights Act of 1866}

Under the enforcement power of the thirteenth amendment, ${ }^{13}$ Congress passed the Civil Rights Act of 1866. ${ }^{14}$ In sweeping terms, section one of that Act guaranteed certain civil rights to all persons born in the

they may claim to be. Guillory v. Administrators of Tulane Univ., 203 F. Supp. 855, 858-59 (E.D. La. 1962) (Wright, J.).

Although some authors have recently expressed approval for this type of argument, see Note, Post-Brown Private White Schools, supra note 4; Comment, Jones v. Alfred H. Mayer Co. Extended to Private Education: Gonzales v. Fairfax-Brewster School, Inc., 122 U. PA. L. REv. 471, 479-82 (1973), no court has adopted such an expansive view of state action. But cf. Marsh V. Alabama, 326 U.S. 501 (1946). Indeed, the position has been undercut by the Supreme Court's holding that education is not a fundamental right. See Independent School Dist. v. Rodriguez, 411 U.S. 1 (1973). The better view, therefore, is that state action can "no longer be heavily relied upon to desegregate private schools. State involvement in private schools has become relatively subtle and provides little basis for finding state action in most cases." Private Schools 1368.

11. Many states have prohibited discrimination in at least some of their private schools. No Southern states are among their number. For a listing of such statutes see Private Groups 1460-61 n.97. Several of the acts are modeled after section 502 of the Model Anti-Discrimination Act of the Commissioners on Uniform State Laws (1966), which states that it is a discriminatory practice for a private or public educational institution "to exclude, expel, limit, or otherwise discriminate against an individual seeking admission as a student . . . in the terms, conditions, and privileges of the institution, because of race, color, religion, or national origin . ..." Although the commentators seem convinced that such statutes are constitutional, see Dorsen, Racial Discrimination in "Private" Schools, 9 WM. \& MARY L. REv. 39, 47 (1967); Fox, Discrimination and Antidiscrimination in Massachusetts Law, 44 BostoN U.L. REv. 30, 71 (1964); Private Groups 1461, they have reportedly been meffective because of sporadic enforceinent. Dorsen, supra, at 48; cf. Symposium, Fair Employment Practices Acts, 14 Buff. L. Rev. 1 (1964). See generally Note, Fair Educational Practices Acts: A Solution to Discrimination?, 64 HARv. L. REv. 307 (1950).

12. 96 S. Ct. 354 (1975).

13. U.S. CoNST. amend. XIII states:

Section 1. Neither slavery nor involuntary servitude ... shall exist within the United States, or any place subject to their jurisdiction.

Section 2. Congress shall have power to enforce this article by appropriate legislation.

14. Act of April 9, 1866, c. 31, § 1, 14 Stat. 27. 
United States.15 It granted the newly enfranchised black the same rights as a white citizen to contract and to buy, sell and hold both real and personal property. ${ }^{16}$

Until recently, however, this section had not been utilized to attack private discrimination because of the Supreme Court's famous decision in the Civil Rights Cases. ${ }^{17}$ There the Court acknowledged that Congress had authority under the thirteenth amendment "to enact all necessary and proper laws for the obliteration and prevention of slavery with all its badges and incidents,"1s but interpreted the phrase "badges and incidents" narrowly. ${ }^{19}$ According to Justice Bradley, applying the thirteenth amendment to every refusal to accommodate a black "would be running the slavery argument into the ground."20

15. The Act actually declared "[t]hat all persons born in the United States and not subject to any foreign power, . . . are hereby declared to be citizens of the United States ...." The Act proceeded to enumerate the rights of such "citizens." Act of April 9, 1866 , c. $31, \S 1,14$ Stat. 27 . In the 1870 reenactment, protection was extended to all persons. Act of May 31, 1870, c. 114, $\$ 16,16$ Stat. 140, 144 (codified at 42 U.S.C. $\S \S 1981 \& 1982$ (1970)).

16. [S]uch citizens, of every race and color, without regard to any previous condition of slavery or involuntary servitude, .... shall have the same right, in every State and Territory im the United States, to make and enforce contracts, to sue, be parties, and give evidence, to inherit, purchase, lease, sell, hold, and convey real and personal property, and to full and equal benefit of all laws and proceedings for the security of person and property, as is enjoyed by white citizens . . . Act of April 9, 1866, c. 31, $\$ 1,14$ Stat. 27, re-enacted by $\$ 18$ of the Enforcement Act of 1870, Act of May 31, 1870, c. 114, \$ 18, 16 Stat. 140,144 (codified at 42 U.S.C. $\$ 1981$ \& 1982 (1970)).

17. 109 U.S. 3 (1883). The Court struck down the Civil Rights Act of 1875 which, in addition to re-enacting the 1866 Act in toto, see note 16 supra, prohibited racial discrimination in the use of "inns, public conveyances on land and water, theatres, and other places of public amusement ...." Act of March 1, 1875, c. 114, $\$$ 1, 18 Stat. 335. For the text of the Act see the Civil Rights Cases, 109 U.S. 3, 9 (1883). Congress asserted that the power for such an enactment flowed from both the thirteenth and fourteenth amendinents. As to the latter amendment, the Court held that state action alone was affected.

18. 109 U.S. at 21.

19. One commentator has pointed out that what is considered by society as a badge and incident of slavery can and does vary with time. "[T] he banning of a man from a restaurant because of his race may well loom much larger as a vestige of slavery [now] than it did in 1883." Larson, The New Law of Race Relations, 1969 WIs. L. Rev. 470, 489-90.

20. 109 U.S. at 24. There was, of course, a famous and spirited dissent by Justice Harlan. He prophesied a second-class citizen status for the freedmen. Id. at 61-62 (Harlan, J., dissenting); see also United States v. Cruikshank, 25 F. Cas. 707 (No. 14,897) (C.C.La. 1874) (Bradley, Circuit Judge), aff'd, 92 U.S. 542 (1875).

In holding that refusing to render services to blacks "has nothing to do with slavery or involuntary servitude," 109 U.S. at 24 , the majority was also seen to have limited legislation under the thirteenth amendment to prohibitions against "enforced compulsory service." See Corrigan v. Buckley, 271 U.S. 323 (1926); Hodges v. United States, 203 U.S. 1 (1906). This reading has been discredited by Jones v. Alfred $H$. Mayer Co., 392 U.S. 409,441 n.78 (1968). 
Eighty-five years later, the Supreme Court scuttled this restrictive approach to Congress' power under the thirteenth amendment in Jones v. Alfred H. Mayer Co ${ }^{21}$ Relying in part on section $1982,{ }^{22}$ a portion of section one of the Civil Rights Act of 1866, Mr. Jones claimed relief because he was denied purchase of a house solely for the reason that he was a black man. The majority, recounting that the thirteenth amendment gives Congress the power to abolisli all "badges and incidents" of slavery, ${ }^{23}$ upleld his claim. ${ }^{24}$ "[W] $]$ hen racial discrimination herds men

With regard to the fourteenth amendment, the majority announced that "state action" must be present. 109 U.S. at 10-11. See generally Note, Federal Power to Regulate Private Discrimination: The Revival of the Enforcement Clauses of the Reconstruction Era Amendments, 74 Colum. L. Rev. 449, 450-54 (1974).

21. 392 U.S. 409 (1968).

22. 42 U.S.C. $\$ 1982$ (1970) provides: "All citizens of the United States shall have the same right, in every State and Territory, as is enjoyed by white citizens thereof to inherit, purchase, lease, sell, hold, and convey real and personal property."

23. 392 U.S. at 439, quoting Civil Rights Cases, 109 U.S. 3, 20 (1883). The majority avoided the question of whether the Civil Rights Cases Court would have regarded the instaut situation as a badge or incident of slavery. See 392 U.S. at 441 n.78. But see id. at 451 (Harlan, J., dissenting); Note, Federal Power to Regulate Private Discrimination, supra note 20 , at $466-68$.

24. The analysis in Jones was straightforward. The Court found, first, that the Fair Housing Title of the Civil Rights Act of 1968, Pub. L. No. 90-284, 82 Stat. 81, did not preempt or undercut section 1982. 392 U.S. at 413-17. After distinguishing several cases, id. at 417-20 (primarily discussed was Hurd v. Hodge, 334 U.S. 24 (1948)), the Court "for the first time," 392 U.S. at 420, confronted the issue of whether section 1982 reached private discrimination. A positive answer was based on a plain reading of the statute, $i d$. at $420-22$, the structure of the statute, id. at 422-26, and its legislative history, id. at 426-37. Finally the Court asked whether Congress had power under the thirteenth amendment to enact section 1982 as construed and concluded that it did. Id. at 43744.

The historical accuracy of the majority's conclusion has been a heated question. Justice Harlan in dissent amassed almost twenty pages of material "to show that those debates do not, as the Court would have it, overwhelmingly support the result reached by the Court, and in fact . . . a contrary conclusion may equally well be drawn." Id. at 454-73.

One commentator has contended that "when legislative history is being adduced to prove that words do not 'mean what they say' it is not enough to show that the inference urged by the dissent, in Justice Harlan's words, 'may equally well be drawn.' Larson, supra note 19 , at 488 . However, Justice Harlan also questioned the self-evident nature of section 1982. 392 U.S. at 452-54.

As to the debate over which historical interpretation is correct, the following authors support the majority position: W. BROCK, AN AMERICAN Crisis 111 et seq. (1963); L. \& J. Cox, Politics, Principle, and Prejudice, 1865-1866 ch. 10 (1963); J. McPherson, The Struggle for EQuality (1965); Kinoy, Jones v. Alfred H. Mayer Co.: An Historic Step Forward, 22 VaNd. L. Rev. 475 (1969); Benedict, Book Review, 39 U. CHI. L. REV. 862, 869-70 (1972). The following authors support the dissent's

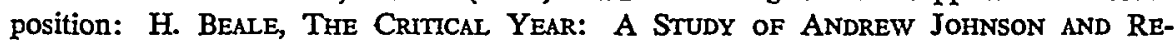
COnStruction (1930); W. Dunning, Reconstruction: Polmtical and Economic 1865-1877 (1907, reissued 1962); 6 C. FaIRMaN, History of tHe SUPREME COURT of The Unired States 1257 et seq. (1971); Casper, Jones v. Alfred H. Mayer Co.: Clio, 
into ghettos and makes their ability to buy property turn on the color of their skin, then it too is a rehic of slavery."25

Two recent Supreme Court opinions have made it clear that the Court no longer intends that section 1982 be read restrictively. In Sullivan v. Little Hunting Park, Inc. ${ }^{26}$ the Court granted damages to a black lessee when the defendant refused to honor the transfer of the lessor's assignable memberslip share solely because of the lessee's race. ${ }^{27}$ Tillman v. Wheaton-Haven Recreational Association, Inc. ${ }^{28}$ presented a sinuilar problem. There a unanimous Court granted relief to a black homeowner under section 1982 when le was not permitted to use the community pool because of his race. ${ }^{29}$ The Court considered the opportunity to enjoy the pool an attractive feature of that particular residential area, and reasoned that denial of the possibility of membership in the pool association abridged and diluted the clainiant's right to acquire a honie. ${ }^{30}$

The lower courts have heeded the Supreme Court's adnuonition that a "narrow construction of the language of $\S 1982$ would be quite inconsistent with the broad and sweeping nature of the protection meant to be afforded by section 1 of the Civil Rights Act of 1866 . . . from which $\S 1982$ was derived . . .."31 Section 1981, also derived from section one of the 1866 Act, sinilarly has been given a broad reading by the courts. ${ }^{32}$ The "same right ... to make and enforce contracts" language has been extended primarily to the employment situation, ${ }^{33}$

Bemused and Confused Muse, 1968 Sup. CT. Rev. 89; Ervin, Jones v. Alfred H. Mayer Co.: Judicial Activism Run Riot, 22 VAND. L. Rev. 485 (1969).

25. 392 U.S. at 442-43. The Court applied the formula of McCulloch v. Maryland, 17 U.S. (4 Wheat.) 316,421 (1819), to demonstrate the constitutionality of section 1982. 392 U.S. at $443-44$.

26. 396 U.S. 229 (1969).

27. Id. at $236,238-40$.

28. 410 U.S. 431 (1973); see 23 CATH. L. Rev. 147 (1973).

29. The plaintiffs also sought to enjoin the association's racially restrictive guest policy under section 1981. 410 U.S. at 439-40. The Court remanded this issue to the lower court, where an injunction was granted. See Tillman v. Wheaton-Haven Recreational Ass'n, 367 F. Supp. 860 (D. Md. 1973), aff'd, 517 F.2d 1141 (4th Cir. 1975).

30. 410 U.S. at 437.

31. Sullivan v. Little Hunting Park, Inc., 396 U.S. 229, 237 (1969); see, e.g., Sims v. Order of United Commercial Travelers, 343 F. Supp. 112 (D. Mass. 1972); Terry v. Elmwood Cemetery, 307 F. Supp. 369 (N.D. Ala. 1969). See generally Brook, Nondiscrimination in Sale or Rental of Real Property: Comment on Jones v. Alfred H. Mayer Co. and Title VIII of the Civil Rights Act of 1968, 22 VAND. L. REv. 455 (1969); Note, Federal Power to Regulate Private Discrimination, supra note 20; 1975 Brigham Young L. Rev. 141; 88 HaRv. L. Rev. 1610 (1975).

32. See generally Note, Federal Power to Regulate Private Discrimination, supra note 20 , at $477-86$.

33. Bowers v. Campbell, 505 F.2d 1155 (9th Cir. 1974) (federal civihan employee 
and the Supreme Court has recently given its approval to such a policy. ${ }^{34}$ In addition, section 1981 has been applied to admission to privately-owned recreational facilities, ${ }^{35}$ private hospitals, ${ }^{36}$ training schools, ${ }^{37}$ and, in McCrary $v$. Runyon, to private elementary schools. ${ }^{38}$

\section{McCrary v. Runyon: Section 1981 aNd PRIVATE EdUCATION}

In McCrary $v$. Runyon the parents of black children learned of the private schools involved through mass mailings addressed to "Resident" and through advertisements in the Yellow Pages of the telephone book. ${ }^{39}$ They inquired about admission at both schools, but in each case were informed that only members of the Caucasian race were accepted. ${ }^{40}$ The parents brought actions under section 1981, alleging that they were being denied the same right as a white citizen to make a

sued the officers of a United States Air Station); Guerra v. Manchester Terminal Corp., 498 F.2d 641 (5th Cir. 1974); Long v. Ford Motor Co., 496 F.2d 500 (6th Cir. 1974); Macklin v. Spector Freight Sys., Inc., 478 F.2d 979 (D.C. Cir. 1973); Brady v. BristolMeyers, Inc., 459 F.2d 621 (8th Cir. 1972); Brown v. Gaston County Dyeing Machine Co., 457 F.2d 1377 (4th Cir.), cert. denied, 409 U.S. 982 (1972); Young v. International Tel. \& Tel. Co., 438 F.2d 757 (3d Cir. 1971); Waters v. Wisconsin Steel Works, 427 F.2d 476 (7th Cir.), cert. denied, 400 U.S. 911 (1970).

34. Johnson v. Railway Express Agency, Inc., 421 U.S. 454 (1975). The Court there stated, "[I]t is well settled among the Federal Courts of Appeals-and we now join them-that $\$ 1981$ affords a federal remedy against discrimination in private employment on the basis of race." Id. at 459-60 (citations omitted). Justices Marshall, Douglas, and Brennan concurred with this statement. See id. at 470-71 (Marshall, J., concurring in part and dissenting in part.).

35. Olzman v. Lake Hills Swim Club, Inc., 495 F.2d 1333 (2d Cir. 1974); Scott v. Young, 421 F.2d 143 (4th Cir.), cert. denied, 398 U.S. 929 (1970).

36. United States v. Medical Soc'y, 298 F. Supp. 145 (D.S.C. 1969). See also Scott v. Eversole Mortuary, 522 F.2d 1110 (9th Cir. 1975).

37. Grier v. Specialized Skills, Inc., 326 F. Supp. 856 (W.D.N.C. 1971).

38. 515 F.2d 1082 (4th Cir. 1975), aff'g Gonzales v. Fairfax-Brewster School, Inc., 363 F. Supp. 1200 (E.D. Va. 1973), cert. granted, 96 S. Ct. 354 (1975).

39. McCrary is a combination of two cases which present nearly identical fact situations. The parents of Colon Gonzales applied at Fairfax-Brewster School after receiving an advertisement in the mail and hearing of the school from a friend whose son attended there. The application was returned. Upon inquiry about the rejection, Mr. Gonzales was informed that the school was not integrated. 515 F.2d at 1084-85.

Both the Gonzaleses and Mrs. McCrary phoned Bobbe's School about enrolling - their sons. They were told that only members of the Caucasian race were accepted. Id. at 1085. No application was made to Bobbe's School, but the majority agreed that it would be "ridiculous to require this of the plaintiffs after they had effectively been told it was useless." Id.

The Southern Independent School Association intervened in both actions. It is an association representing more than 300 private, nonprofit schools in the South, some of which it concedes are racially discriminatory. The position of the Association is that such discrimination is not prohibited by section 1981 and, in any event, cannot be constitutionally prevented. See id. at 1084.

40. Id. at 1085 . 
contract. The district court, in a inuch noted opinion, ${ }^{41}$ agreed, found section 1981 applicable, and granted relief. ${ }^{42}$

The Fourth Circuit, in affirming the district court decision, first rejected the contention ${ }^{43}$ that section 1981 had only the limited objective of removing the legal disabilities of the Black Codes. ${ }^{44}$ Relying lieavily on Jones and Tillman and noting that sections 1981 and 1982 have a common origin, the majority answered that the statute certainly did nullify suclı state laws. But, the court added, "it did much more than that." S5 Section 1981, hike section 1982, was intended to prohibit all discrimination against nonwhites, ${ }^{46}$ private as well as state-sanctioned. ${ }^{47}$

The court next disposed of constitutional challenges to the statute on the basis of the defendants' freedom of association and their right of

41. See Note, Federal Power to Regulate Private Discrimination, supra note 20; Private Schools; Is 1981 the Answer?; Comment, Jones v. Alfred H. Mayer Co., supra note 10; Segregation Academies; 11 Houston L. Rev. 691 (1974); 7 LoYola of L.A.L. Rev. 634 (1974); 45 Miss. L.J. 246 (1974); 42 U. CIN. L. REv. 767 (1973).

42. Gonzales v. Fairfax-Brewster School, Inc., 363 F. Supp. 1200 (E.D. Va. 1973), aff'd sub nom. McCrary v. Runyon, 515 F.2d 1082 (4th Cir.), cert. granted, 96 S. Ct. 354 (1975).

43. The majority preliminarily disposed of the assertion that the facts as found by the district court were clearly erroneous. 515 F.2d at 1085-86.

44. Apparently overlooked by the majority was the fact that it was a felony in the slave states to teach slaves to read and write prior to the adoption of the thirteenth amendment. See, e.g., GA. Stat. LAw ch. xxx, $\S \S 59$ \& 60 (Hotchkiss 1848) (prohibited teaching slaves to read and write); id. $\$ 61$ (prohibited sale of books to slaves or colored persons for their own use); id. $\$ 62$ (prohibited employing slaves or colored persons in printing offices). One commentator has sought to demonstrate that one of the purposes of the thirteenth amendment was to provide equal education for blacks even though the statutory history of the Civil Rights Act of 1866 does not specifically mention education. See Note, The Thirteenth Amendment and Education: An Unfulfilled Promise, 20 S.D.L. REv. 418 (1975). Among the passages from the debates garnered in support of this thesis is the following statement of Senator Wilson:

If this amendment shall be incorporated . . . into the Constitution . . ., it will obliterate the last lingering vestiges of the slave system; its chattelizing, degrading, and bloody codes. ... [T]he school-house will rise to entighten the darkened intellect of a race imbruted by long years of enforced ignorance. 34 CoNG. GLOBE, 38th Cong., 1st Sess. 1324 (1864), cited in Note, supra, at 423-24.

Senator Johnson used the rhetorical:

Why are these poor creatures kept in a state of absolute ignorance? Why is education, the most humble, denied them? Why are the Holy Scriptures kept from their hovels? Why? Can there be but one answer: that if they knew what knowledge imparts, if they knew what the gospel of our Savior inculcates, they would be freemen, or sooner or later die in the effort to obtain it? 34 CONG. GLOBE, supra, at 1424.

45. 515 F.2d at 1086 .

46. See Jones v. Alfred H. Mayer Co., 392 U.S. 409, $421-22$ (1968).

47. 515 F.2d at 1086-87. The majority also quickly rejected the far-fetched notion that for section 1981 to come into play admission to the school would have to be open to all white citizens. Of course, many white people are restricted because of academic or financial background, age, and even geography from entering an elementary school. 
privacy. Freedom of association provides no help to the schools here, the court held, because the discontinuance of their discriminatory admission practices would in no way inhibit the teaching of any ideas or dogma. ${ }^{48}$ Likewise, section 1981 does not impede parents from sending their children to private schools which present ideas or use educational methods which are not available in the public schools. ${ }^{49}$ Turning to the right of privacy, the court acknowledged that certain "intimate and private affairs" are constitutionally protected from intrusion. ${ }^{50}$ The court, however, did not find application of this principle appropriate in the case: "[w] hen a school holds itself open to the public, . . . or even to those applicants meeting establisled qualifications, there is no perceived privacy of the sort that has been given constitutional protection." $" 51$

\section{SECTION 1981: AN INTERPRETATION}

The majority opimion in $\mathrm{McCrary}$, examined in the light of prior Supreme Court holdings, apparently is the correct one. The dissenting nembers of the Fourth Circuit argued, however, that section 1981 was not intended to reach purely private discrimination in education. ${ }^{52}$ In addition, they urged that extending the reach of the statute into the private school context would create impermissible conflicts with the

Similar facts did not bar application of section 1982 in Sullivan and Tillman. The proper application of the statute looks to the "qualified class." Id. at 1087. If both whites and nonwhites are included in that class, then section 1981 (and section 1982) forbids the nonwhites of the class to be accorded inferior rights solely because of their race. See notes 86-91 infra and accompanying text.

48. Id. at 1087; cf. NAACP v. Alabama, 357 U.S. 449, 460 (1958).

49. 515 F.2d at 1087. See also Pierce v. Soc'y of Sisters, 268 U.S. 510 (1925).

50. 515 F.2d at 1088. See also Roe v. Wade, 410 U.S. 113 (1973); Griswold v. Connecticut, 381 U.S. 479 (1965).

51. 515 F.2d at 1088 . The majority also refused to read Norwood v. Harrison, 413 U.S. 455 (1973), as providing a constitutionally protected right to discriminate. 515 F.2d at 1088. The statement undoubtedly relied on most strongly by the petitioners was the following: "This case does not raise any question as to the right of citizens to maintain private schools with admission limited to students of particular national origins, race or religion ..." 413 U.S. at 457 . The obvious intent here, though, was to leave the issue open. The Court in Norwood also stated: "Such private bias is not barred by the Constitution, nor does it invoke any sanction of laws, but neither can it call on the Constitution for material aid from the State." Id. at 469. The Court, however, went on to qualify this statement by noting that "even some private discrimination is subject to special remedial legislation in certain circumstances under $\$ 2$ of the Thirteenth Amendment . . . ." Id. at 470 . Of course, section 1981 is such remedial legislation passed under the thirteenth amendment. Thus, the McCrary dissent's recourse to Norwood, 515 F.2d at 1096-97, is particularly unpersuasive. See also Private Schools 1389-91.

52. 515 F.2d at 1093-94. 
constitutional rights of privacy and freedom of association. ${ }^{83}$ Testing the validity of these objections must begin with an interpretation of the statute itself.

\section{A. Section 1981 Reaches Private Discrimination}

The dissenting judges in McCrary suggested that section 1981 should not be read as broadly as was section 1982 in Jones and Sullivan. However, in addition to the dissenters' colleagues on the Fourth Circuit, the eight other circuits that have considered the question have all rejected such a reading, ${ }^{54}$ agreeing that the two sister statutes must be treated similarly. The key point is that both section 1981 and section 1982 are derived from the same section of the 1866 Act. That provision was artificially divided upon codification, ${ }^{55}$ a fact recognized by the Supreme Court in Jones and in Tillman. ${ }^{56}$ More importantly, the Court in Jones overruled a prior decision which had interpreted section 1981 narrowly. ${ }^{57}$ Finally, to put an end to the suggestion that section 1981 does not reach purely private discrimination, attention should be given to the recent case of Johnson v. Railway Express Agency, Inc., ${ }^{68}$ where the Supreme Court unanimously confirmed that section 1981 reaches private discrimination in the context of employment. ${ }^{58}$

53. Id. at 1094-96.

54. See Faraca v. Clements, 506 F.2d 956 (5th Cir. 1975); Bowers v. Campbell, 505 F.2d 1155 (9th Cir. 1974); Long v. Ford Motor Co., 496 F.2d 500 (6th Cir. 1974); Olzman v. Lake Hills Swim Club, Inc., 495 F.2d 1333 (2d Cir. 1974); Baker v. F \& F Investment Co., 489 F.2d 829 (7th Cir. 1973); Macklin v. Spector Freight Sys., Inc., 478 F.2d 979 (D.C. Cir. 1973); Brady v. Bristol-Meyers, Inc., 459 F.2d 621 (8th Cir. 1972); Young v. International Tel. \& Tel. Co., 438 F.2d 757 (3d Cir. 1971).

55. Section 1 of the Civil Rights Act of 1866,14 Stat. 27 , was initially codified in sections 1977 and 1978 of the Revised Statutes of 1874 .

56. See 392 U.S. at 422 n. $28 ; 410$ U.S. at $439-40$.

57. 392 U.S. at 441 n.78. The case overruled was Hodges v. United States, 203 U.S. 1 (1906). In Hodges it was held that several black men had no cause of action under section 1981 when a group of white inen assaulted and "terrorized" them in order to prevent their working in a sawmill. The majority reasoned that this activity did not operate "to reduce the individual to a condition of slavery," $i d$. at 18 , and thus was not reached by the thirteenth amendment.

58. 421 U.S. 454 (1975).

59. Id. at $459-60,470-71$. Justice Marshall in concurrence stated the position of the Court:

A full exposition of the statutory origins of 1981 with respect to prohibition against private acts of discrimination is set out in Jones $v$. Alfred $H$. Mayer Co. In construing $\S 1982$, a sister provision to $\$ 1981$, we concluded that Congress intended to prevent private discriminatory deprivations of all the rights enumerated in $\S 1$ of the 1866 Act, including the right to contract. The Court's recognition of a proscription in $\$ 1981$ against private acts of employment discrimination .... reaffirms that the early Civil Rights Acts reflect congressional intent to "speak ... of all deprivations ... whatever their 
The $\mathrm{McCrary}$ dissent also asserted that the word "right" in sections 1981 and 1982 does not necessarily have the same meaning in all contexts. A inere freedoin from legal disability to own property would be of hittle value if no owner would sell to a black man. Section 1982, then, unust reach the private real estate market if a black man is not to be demed the "right" to own and enjoy property. But, the dissent argued, public schools and nondiscriminatory private schools carry the vast bulk of the education burden in this country. Consequently, a nonwhite would not be demed a substantial right to an education if section 1981 were not given full play.

This argument fails on both practical and legal grounds. Practically speaking, no parent pays both public school taxes and private school tuition unless he feels that his child is receiving a substantial additional benefit from the private school. ${ }^{60}$ As a legal matter, the word "right" lias the same meaning in section 1981 as in section 1982 smce only one "right" was mentioned in section one of the 1866 Act. ${ }^{61}$ Moreover, the reasoning urged by the dissent not only requires divergent readings of the word "right," but also of the word "contract." A contract of employment would be within the purview of section $1981,{ }^{62}$ but a contract for education would not. The necessity of ad hoc inquiry each time a complex or new type of contract is presented to the court militates strongly against any such approach.

source." Id. at 471 (emphasis in original) (citations omitted), quoting Griffin v. Breckenridge, 403 U.S. 88, 97 (1971).

See also Tillman v. Wheaton-Haven Recreational Ass'n, 410 U.S. 431 (1973). In Tillman the Court remanded the case for consideration of whether the association's racially restrictive guest policy should be struck down under section 1981 . On remand the court struck it down. See Tillman v. Wheaton-Haven Recreational Ass'n, 367 F. Supp. 860 (D. Md. 1973), aff'd, 517 F.2d 1141 (4th Cir. 1975).

60. Situations can be easily imagined where the education provided in private schools in the area is vastly superior to that of the public schools. This situation is at least partially exacerbated by the white flight to segregation academies. The public schools are made substantially one-race schools again and Brown is sapped of its vitality. See Is 1981 the Answer? 1171-72. See generally Segregation Academies. In addition, in some cases the choice is between a private school or no school, such as when a child misses the first grade or kindergarten age cutoff for the state. In Durham, North Carolina, there is a lottery each year to allocate the few spaces available in the public kindergartens.

The argument that there are other private schools available which do not have discriminatory admissions policies is not convincing because, first, there are often no acceptable substitutes, especially in smaller communities, and, second, even if there are, the parents have demonstrated that the school in question best suits their and their child's needs by the very fact of application. Surely the choice of a school is for the parents to make. Cf. Pierce v. Society of Sisters, 268 U.S. 510, 534-35 (1925).

61. For the text of the statute see note 16 supra.

62. Johnson v. Railway Express Agency, Inc., 421 U.S. 454, 459-60 (1975). 


\section{B. What Is the "Same Right"?}

In Smith v. Sol D. Adler Realty $\mathrm{Co}^{\theta 3}$ a Seventh Circuit panel granted relief to a black woman under section 1982 when her race was only one of several factors in a negative apartment rental decision. ${ }^{64}$ The district court had demied relief because, although some racial animus was present, a white woman would have been rejected as a tenant under the same circumstances. ${ }^{85}$ The appellate court's decision must be rejected since it violates logic, precedent, and a common-sense reading of the statutory language. ${ }^{86}$

The Smith panel founded its conclusion on the statement in Jones that the Civil Rights Act of 1866 applies to all racial discrimination. ${ }^{67}$ However, exammation of the context in which this statement is made clearly reveals that by "all" the Supreme Court simply meant that the Act reaches botll private and governmental activity. ${ }^{68}$ In addition the Court liad earlier stated that "whatever else it may be . . . § 1982 is not a comprehensive open housing law." 89

Although it has not explicitly ruled on the matter, the Supreme Court has been exceedingly careful in its 1866 Act decisions to point out that racial discrimination lias been the only reason for the denial of rights. In other words, the demial would not have occurred "but for" the racial factor. ${ }^{70}$ This was the state of the record in Jones, ${ }^{71}$ in Sullivan where the Court found Little Hunting Park to be open to all whites in the geographical area, "there being no selective eleinent other

63. 436 F.2d 344 (7th Cir. 1970).

64. The court stated, 'We read this to hold that the 'same right' means that race is an impermissible factor in an apartment rental decision and that it cannot be brushed aside because it was neither the sole reason for discrimination nor the total factor of discrimination. We find no acceptable place in the law for partial racial discrimination." Id. at 349-50.

65. Mrs. Smith had a child and the apartments had an established policy against renting to employed parents with infant children. Id. at 349 .

66. But see Private Schools 1383-84 (result in Smith defended).

67. 436 F.2d at 349, citing Jones v. Alfred H. Mayer Co., 392 U.S. 409, 421-22 (1968).

68. See Jones v. Alfred H. Mayer Co., 392 U.S. 409, $421-22$ (1968). "On its face, therefore, $\$ 1982$ appears to prohibit all discrimmation against Negroes in the sale or rental of property-discrimination by private owners as well as discrimination by public authorities." Id. at 421.

69. Id. at 413. In comparison, note that in an action under the Fair Housing Act, 42 U.S.C. $\$ \S 3601$ et seq. (1970), "[i]t is enough that race was one significant factor [the defendant] considered in his dealings with the men." United States v. Pelzer Realty Co., 484 F.2d 438, 443 (5th Cir. 1973).

70. See Riley v. Adirondack S. School for Girls, 368 F. Supp. 392, 398 (M.D. Fla. 1973).

71. 392 U.S. at 412. 
than race,"72 and in Tillman where the Court again found "no plan or purpose of exclusiveness" except race. ${ }^{73}$

The Fourth Circuit properly followed the Supreme Court precedent in McCrary:

What we have said should not be read to call into question the right of the school to insist upon an evenhanded requirement of academic and other racially neutral qualifications. Indeed, the right of the school to be selective on these bases is unquestioned here. All that is contended and all that we hold is that $\S 1981$ prohibits the rejection of a black applicant when his qualifications ineet all other requirements and race is the only basis for his rejection. ${ }^{74}$

The conclusion of the Fourth Circuit is strongly supported not only by precedent but by a common-sense reading of section 1981 . The statute guarantees to all citizens the same, or equal, right as white citizens to perform certain acts. The purpose of the statute was to put the races on the same footing. It granted blacks equal, not superior, rights.

Section 1981 does not begin to operate until the appropriate class of people is ascertamed. For instance, obviously not every citizen can join the Boy Scouts, for the organization imposes valid restrictions on both sex and age. ${ }^{75}$ Assuming that the eligible group consists of male

72. 396 U.S. at 236.

73. 410 U.S. at 438, quoting Sullivan v. Little Hunting Park, Inc., 396 U.S. 229, $236(1969)$.

74. $515 \mathrm{~F} .2 \mathrm{~d}$ at 1087 (emphasis added). Later, speaking more generally, the court elaborated:

Indeed, $\S 1981$ does not purport to reach all private associations. It reaches only those which evidence "no plan or purpose of exclusiveness" other than race .... Private associations having non-racial criteria for the selection of members may apply their criteria, even if it results in a disproportionate impact upon the members of one race. It is only when blacks are excluded because they are black, or denied a right to contract which would be granted were they white, that $\S 1981$ is violated. Id. at 1088, citing Sullivan v. Iittle Hunting Park, Inc., 396 U.S. 229 (1969).

See also Boyd v. Lefrak Organization, 509 F.2d 1110 (2d Cir. 1975) (landlord's racially neutral renting requirement upheld even though it disproportionately affected blacks and Puerto Ricans); Madison v. Jeffers, 494 F.2d 114 (4th Cir. 1974) (owner who took land off market because of tax advice rather than for racial reason not liable under section 1982, notwithstanding the fact that such tax advice later proved erroneous). "The civil rights statutes as interpreted make clear that one who sells or leases real estate '[has] a right to refuse approval on any honest basis unrelated to the race of the prospective purchaser.'" Id. at 117, quoting Pughsley v. 3750 Lake Shore Drive Cooperative Bldg., 463 F.2d 1055, 1066 (7th Cir. 1972).

75. Even this position, however, has undergone recent court challenges. Cf. Magill v. Avondale Baseball Conference, 516 F.2d 1328 (3d Cir. 1975) (case dismissed on finding of insufficient state action); Fortin v. Darlington Little League, Inc., 514 F.2d 344 (1st Cir. 1974) (finding of state action resulted in remand to determine if injunction prohibiting discrimination on basis of sex should issue). See also N.Y. Times, Sept. 
citizens between the ages of ten and eighteen, the next inquiry is whether any nonwhites are nembers of this qualified class. ${ }^{76}$ If so, section 1981 dictates that they cannot be denied admission solely on account of their race. ${ }^{77}$ Stated sonewhat differently, a black man of twenty-five could not compel his acceptance into the Boy Scouts even if the organization had a racially discriminatory admissions policy. $\mathrm{He}$ would be legitimately excluded for the nonracial reason that he was too old. ${ }^{78}$

It has been argued that utilization of the "but for" test in section 1981 cases makes enforcentent "practically mipossible" since, if a defendant niay consider race, other selective elements are likely to be inere excuses. ${ }^{79}$ It is further suggested that the existence of other factors which justify rejection should go only to the issue of damages. ${ }^{80} \mathrm{Al}-$ though admittedly there is some reason for concern in this area, the danger does not necessitate a tampering with the plain language of section 1981. Congress has provided other comprehensive remedies against racial discrimination, most notably in the Civil Rights Acts of

28, 1975, at 35, col. 1 (Cub Scout pack charter revoked for having female pack leader where organization bylaws require a man).

76. See Love v. DeCarlo Homes, Inc., 482 F.2d 613 (5th Cir.), cert. denied, 414 U.S. 1115 (1973). In Love blacks alleged that they were sold homes at exorbitant and onerous prices due to a scarcity of housing in the area. The Fifth Circuit dismissed their section 1981 claim because they had presented no evidence showing that whites were sold homes on more favorable terms. But see Clark v. Universal Builders, Inc., 501 F.2d 324 (7th Cir.), cert. denied, 419 U.S. 1070 (1974).

77. The adverb "solely" is used here to indicate that even if a black is a member of the class, he is still not guaranteed admission any more than a white member of the class. For instance, there could be 100 potential class inembers all seeking ten available positions. Both a lottery and a first come-first served waiting list method would be acceptable, nonracial methods of differentiating among members of the class. Race, of course, would not be.

78. The court in Riley v. Adirondack S. School for Girls, 368 F. Supp. 392 (M.D. Fla. 1973), gives the following example:

Assume ... that Black aud White simultaneously apply for unembership in any given organization. Black is refused for reasons $R$ (race) and $X$ (age or sex or any other nonpretextual, albeit arbitrary criteria). White is also refused due to reason $\mathrm{X}$ alone. Black has been victimized by racial discrimination, but his right to contract was the same as that enjoyed by White. That is, even if the race factor had been eliminated ...., the result would remain precisely the same, and would have been obtained for the same reason. And, under those circumstances, if the racial consideration was deemed to be violative of the statute and thus remediable, the inevitable effect would be to confer upon Black a higher or superior right to contract, not the same or equivalent right. Id. at 398.

It should be noted that the conclusion of the court in Riley that the nonracial criteria for rejection of the black child were not mere pretexts is far from convincing. See Private Schools 1383-84 \& n.112; Is 1981 the Answer? 1173-74 (criticizes Riley for mixing the "but for" test and the private club sole criterion distinction).

79. Private Schools 1383.

80. Id. at 1384 . 
$1964^{81}$ and the Civil Obedience Act of $1968 .^{82}$ Moreover, the federal courts have had long experience in the art of disposing of pretexts designed to mask unlawful discrimination. ${ }^{83}$ In sum, if the reason is not a mere pretext, the plaintiff should have no right of action and damages, mitigated or otherwise, should not be awarded.

Since both section 1981 and section 1982 guarantee to nonwhites only the "saine right[s]" enjoyed by white citizens, the scope of the protection afforded by the two sections cannot be ascertained without asking exactly what rights whites have in the relevant contexts. In the case of section 1981, one inust understand what right a white citizen has to "inake and enforce . . . a contract"; for section 1982, the question is what right does a white citizen have to "purchase" or "sell" property. The precise issue being examined here would seem to belabor the obvious. Nevertheless, the failure to come to grips with the question has led the courts ${ }^{84}$ and the commentators ${ }^{85}$ to attribute an unwarranted scope to these sections.

The point, which has yet to be sufficiently articulated, is that no person, white or black, can legally force another to accept his offer. A simple example framed in terms of section 1982's guarantee of the "same right to . . . purchase" real property will illustrate the point which, it should be stressed, also limits the protection of section 1981. Jones, a black man, wishes to buy a house now owned by Smith. If Sinith places his house on the market, with ads in the local paper and a "for sale" sign on the front lawn, there is now no doubt that Jones does have a right to purchase Smith's home. ${ }^{86}$ That is, if Jones "accepts"

81. Pub. L. No. 88-352, 78 Stat. 241 (codified at various sections of titles $5,28, \& 42$ U.S.C.). Specific remedies are provided in 42 U.S.C. $\$ \S 1971,1975 a-d, 2000$ a to h-6 (1970).

82. Pub. L. No. $90-284,82$ Stat. 81 (codified at various sections of titles 18,25 , $28, \& 42$ U.S.C.).

83. Such superficial reasons were discarded by the court in McCrary itself, 515 F.2d at 1084-86. See also Griggs v. Duke Power Co., 401 U.S. 424 (1971); Green v. County School Bd., 391 U.S. 430 (1968); Griffin v. County School Bd., 377 U.S. 218 (1964); Williams v. Matthews Co., 499 F.2d 819 (8th Cir.), cert. denied, 419 U.S. 1021 (1974); Olzman v. Lake Hills Swim Club, Inc., 495 F.2d 1333, 1340-42 (2d Cir. 1974); cf. Clark v. Universal Builders, Inc., 501 F.2d 324 (7th Cir.), cert. denied, 419 U.S. 1070 (1974); Note, Racial Discrimination in Public Housing: Rights and Remedies, 41 U. CHI. L. Rev. 582, 584-94 (1974). But cf. McAdory v. Scientific Research Instruments, Inc., 355 F. Supp. 468 (D. Md. 1973).

84. See, e.g., Cornelius v. Benevolent Protective Order of Elks, 382 F. Supp. 1182, 1198 (D. Conn. 1974).

85. See, e.g., Comment, Jones v. Alfred H. Mayer Co., supra note 10, at 476-79.

86. See Jones v. Alfred H. Mayer Co., 392 U.S. 409 (1968). This example does not intend to consider what relevance other statutes, such as the Fair Housing Act, 42 U.S.C. $\$ \$ 3601$ et seq. (1970), may have. See Johnson v. Zaremba, 381 F. Supp. 165 
Smith's offer by tendering the requested purchase price, ${ }^{87}$ Smith cannot refuse to go through with the deal solely because he prefers not to sell to a black. Any other interpretation of the statute would not guarantee to Jones the "same right" that a white citizen would have in this situation-any white citizen who "accepts" the terms of Smith's offer by tendering the requested price would have a right to enforce this unilateral contract. 88

If, however, Smith has not "offered" to sell his house in a inanner such that a unilateral contract is formed, Jones cannot force him to sell the house simply by tendering the fair market value (or a higher figure) of the property. This is so even though Smith's motive in refusing to sell is wholly discriminatory. In other words, even though Smith would have sold the house to any white person who made the same offer that Jones did, Smith is immune from a section 1982 action so long as he has not placed the house on the market. ${ }^{89}$ Agaim, this understanding of

(N.D. Ill. 1973) (Fair Housing Act and Civil Rights Act of 1866 give complementary but distinct remedies).

87. Corbin states that an "offer creates a power of acceptance in the offeree." 1 A. CoRbin, Contracts $\$ 11$, at 24 (1963). Explaining further, he writes, "An offer is an act on the part of one person whereby he gives to another the legal power of creating the obligation called contract. An acceptance is the exercise of the power conferred by the offer, by the performance of some other act or acts. Both offer and acceptance must be acts expressing assent." Id. at 24 n.18. See also Moore v. Townsend, 525 F.2d 482 (7th Cir. 1975) (offeror's attempt to reject acceptance due to race not allowed).

88. "A unilateral contract consists of a promise or group of promises made by one of the contracting parties only. . ." 1 A. CoRBIn, supra note 87, 8 21, at 31 (1963). See generally id. \$\$ $62-94$ (acceptance of an offer); id. \& 152 (mutuality); 1 W. JARGER, WILLISTON ON CONTRACTs $\$ \S 13,64-69,102-02 A$ (3d ed. 1957) (consideration). We are assuming that the example given in the text is a unilateral contract offer. Of course, whether it is such an offer or is merely an invitation requesting offers is a factual question to be resolved in each case. See 1 A. Corbin, supra note 87, § 23. For discussion of the proper treatment of invitations under sections 1981 and 1982 see notes 9297 infra and accompanying text.

There is no need for a new federal common law of contracts to be developed especially for section 1981 actions. Since the statute guarantees the same right to all persons, utilizing the law of the jurisdiction in which the court sits will be permissible and proper since its application will be evenhanded with respect to whites and nonwhites. Simply put, applying a federal cominon law different froin the applicable state law in a section 1981 action would be denying a black man the "same right" which a white citizen of the state has, regardless of whether it helped or hurt the particular nonwhite litigant in a particular circumstance. See Player v. Dep't of Pensions \& Security, 400 F. Supp. 249 (M.D. Ala. 1975).

89. This is not to say that Smith's motive for the refusal is relevant to this stage of a section 1981 or 1982 inquiry. It is not. The important consideration is that no white person has a right to force him to sell his property. See notes 90-91 infra and accoinpanying text. Consequently, since a black person has only the same right as a white person, Jones as a black man cannot force the sale either. This fully comports with contract law since no one can create a legally enforceable obligation with another solely by rea- 
the statute's scope flows directly from the "same right" language. No white citizen whose offer to purchase is rejected by Smith has any legal right to force Smith imto the transaction, making Jones" "same right" in actuality "no right." (Indeed, any other interpretation of the section would be unconstitutional. ${ }^{80}$ ) To give Jones relief would be to grant him a greater right than a white citizen would have had ${ }^{01}$

An intermediate situation between a unilateral contract and a forced sale is presented when an invitation rather than an offer is extended by an individual wishing to sell property or make a contract. ${ }^{92}$ In such a case the invitee is not given the power to immediately create a legal obligation..$^{93}$ The invitor can reject any subsequent offers made to him for any reason. Again, at this point the 1866 Act may not be utilized since neither blacks nor whites can force an acceptance. The situation is changed, however, when the sole reason for rejection of a black $^{94}$ is his race. ${ }^{95}$ Here a black is being demed the same right as a

son of his own, non-solicited act. Noble v. Williams, 150 Ky. 439, 150 S.W. 507 (1912).

90. Only in eminent domain proceedings may a property owner be forced to accept an offer, and then only on the basis of the public good, not a private whim. See Missouri Pac. Ry. v. Nebraska, 164 U.S. 403 (1896); City of Charlotte v. Heath, 226 N.C. 750, 40 S.E.2d 600 (1946). See generally 26 AM. JUR. 2D Eminent Domain \$§ 25, 26 (1966). In Missouri Pacific the Court stated, "The taking by a State of the private property of one person or corporation, without the owner's consent, for the private use of another, is not due process of law, and is a violation of the Fourteenth Article of Amendment of the Constitution of the United States." 164 U.S. at 417. Cf. Buchanan v. Warley, 245 U.S. 60, 74 (1917): "Property is more than the niere thing which a person owns. It is elementary that it includes the right to acquire, use, and dispose of it. The Constitution protects these essential attributes of property. Property consists of the free use, enjoyment, and disposal of a person's acquisitions without control or diminution save by the law of the land." Accord, Lynch v. Household Finance Corp., 405 U.S. 538, 544 (1972).

91. See Riley v. Adirondack S. School for Girls, 368 F. Supp. 392, $397-98$ (M.D. Fla. 1973).

92. See generally 1 A. CorbnN, supra note 87 , §§ 22-28. See also Restatement OF CONTRACTS $\S 25$ (1932).

93. It is open to both whites and blacks to prove, of course, that what one party claimed to be an invitation was in reahty an offer which was accepted by the plaintiff. See, e.g., Jenkins Towel Serv., Inc. v. Fidelity-Philadelphia Trust Co., $400 \mathrm{~Pa}$. 98, 161 A.2d 334 (1960); Lefkowitz v. Great Minneapolis Surplus Store, Inc., 251 Minn. 188, 86 N.W.2d 689 (1957).

94. See Seaton v. Sky Realty Co., 491 F.2d 634 (7th Cir. 1974); Johnson v. Jerry Pals Real Estate, 485 F.2d 528 (7th Cir. 1973). See also Faraca v. Clenents, 506 F.2d 956 (5th Cir. 1975) (employment).

95. Whether a white plaintiff has standing under the 1866 Act has not yet been defmitively determined. Compare McDonald v. Santa Fe Trail Transp. Co., 513 F.2d 90 (5th Cir.), cert. granted, 96 S. Ct. 264 (1975); Cahill v. Cedar County, 367 F. Supp. 39 (N.D. Iowa 1973), aff'd, 414 U.S. 806 (1974); Marshall v. Plumbers \& Steamfitters Local 60, 343 F. Supp. 70, 72 (E.D. La. 1972); Perkins v. Banster, 190 F. Supp. 98, 99 (D. Md.), aff'd, 285 F.2d 426 (4th Cir. 1960); with Carter v. Gallagher, 452 F.2d 315, 
white citizen because every comparably situated white citizen who so desires will have entered into a contractual relationship with the former invitor. ${ }^{96}$ The litigant's claim will be that he meets all the race-neutral qualifications and reservations which prevented the invitation from being an offer and, consequently, his rejection was solely due to race. ${ }^{97}$ If he proves such a claim, sections 1981 and 1982 require that he be granted relief.

325 (8th Cir. 1971), modified, 452 F.2d 327 (en banc), cert. denied, 406 U.S. 950 (1972); Spiess v. C. Itoh \& Co., 44 U.S.L.W. 2379 (S.D. Tex. Jan. 29, 1976); Baca v. Butz, 394 F. Supp. 888 (D.N.M. 1975); Hollander v. Sears, Roebuck \& Co., 392 F. Supp. 90 (D. Conn. 1975). See also Tillman v. Wheaton-Haven Recreational Ass'n, 410 U.S. 431 (1973) (whites brought action after their black guest was refused admission); Sullivan v. Little Hunting Park, Inc., 396 U.S. 229 (1969) (a white was given standing as the only effective adversary to redress discrimination agamst a black). See generally Private Groups 1448 n.40; 21 WaYNe ST. L. Rev. 157 (1974).

This Note throughout refers to blacks as the litigating class. Of course, if whites are granted standing in a particular case, the appropriate designations can easily be reversed.

96. Since every similarly situated white will, by definition, have entered into a contract, there will never be any challenge in the courts by a white person. It is exactly because the invitor has entered into a contract with a white individual, or would have if an appropriately situated white had presented himself, that a black meeting the same nonracial criteria and with a prior or equal claim is not accorded the same right. In such a situation it is confusing to regard the transactions as pre-contractual negotiations. Except for the improper motivation, both parties would intend a binding, contractual relationship. Thus, as opposed to the situation where an offer is extended but the contract relationship denied after acceptance has taken place, only blacks will litigate this issue. Compare Jenkins Towel Serv., Inc. v. Fidelity-Philadelphia Trust Co., $400 \mathrm{~Pa}$. 98, 161 A.2d 334 (1960), with Seaton v. Sky Realty Co., 491 F.2d 634 (7th Cir. 1974).

An invitor may retract his invitation, of course, see Madison v. Jeffers, 494 F.2d 114 (4th Cir. 1974), but this technique may not be used as a subterfuge to escape dealings with a black. Id. Cf. McDonnell Douglas Corp. v. Green, 4i1 U.S. 792, 802 (1973) (litigant alleging hiring discrimination must show that the employer continued to seek applications for the opening after rejecting the plaintiff); Keely v. Westinghouse Elec. Corp., 404 F. Supp. 573 (E.D. Mo. 1975).

97. The black litigant's burden of proof will be most easily met when a number of whites have entered into the saine contractual relationship which has been denied him. See, e.g., McCrary v. Runyon, 515 F.2d 1082 (4th Cir.), cert. granted, 96 S. Ct. 354 (1975). In such a case, every race-neutral qualification claimed by the invitor must be satisfied by each white individual. A more difficult case is presented when only one white has contracted, for then a defendant can try to pinpoint any number of idiosyncracies which that individual may have and claim them as qualifications implicit in his invitation. See, e.g., Seaton v. Sky Realty Co., 491 F.2d 634 (7th Cir. 1974); cf. Brown, Givelber \& Subrin, Treating Blacks, As If They Were White: Problems of Definition and Proof in Section 1982 Cases, 124 U. PA. L. Rev. 1, 29-42 (1975). Harder yet to win will be the suit in which no whites have responded to the invitation. See, e.g., Contract Buyers League v. F \& F Investment, 300 F. Supp. 210 (N.D. Ill. 1969), aff'd sub nom. Baker v. F \& F Investinent, 420 F.2d 1191 (7th Cir.), cert. denicd, 400 U.S. 821 (1970). Here an acceptable white class will have to be hypothesized. Even this burden, however, is a function of the number of blacks rejected since each will have to fail the race-neutral qualification(s) claimed by the defendant. 
Further examination of the "same right" language reveals, however, that an offeror or invitor can correspondingly restrict the scope of sections 1981 and 1982 by limiting the class of offerees or invitees. To continue the previous example, suppose that Smith offers his house to five of his close associates, all of whoin are white. Jones, seeking to purchase the house, cannot use section 1982 to force Smith to sell to him. The reason is clear. No white citizen outside Smith's small circle of friends would have any right to compel a sale, and thus, even if Smith's sole motive in refusing to sell to Jones is race, there is no rehef. The same result would obtain if Smith had endeavored to sell his house by offering it to every white individual he met on Main Street, intentionally bypassing every black. In this circumstance, too, no white citizen who had not been approached would have any right to compel Smith to sell lim his home. Consequently, Jones, even if bypassed, would similarly have no such right..$^{98}$

Still another variation of this situation can be readily imagined. Smith could place an advertiseinent in the local newspaper offering to sell his house but attempt to restrict the offer by stating, "This offer is only extended to members of the Caucasian race."99 Here, an action under section 1982 would be available to Jones. Any white citizen tendering the price asked in the ad would have a legal right to enforce Smith's unilateral offer to sell. To allow Smith to exclude Jones from the class of potential buyers by this simple device would be to deny to Jones the "same right" that a white purchaser would have. Even though Jones was never a member of the offeree class as defined by Smith, section 1982 would be applicable. The courts have made this point clear in holding that the class of offerees or invitees must be defined only by race-neutral criteria. ${ }^{100}$

98. It should be emphasized that the intinacy of the relationship is irrelevant. If an offeror goes to the trouble of limiting the class of potential white offerees in a manner which would guarantee that no excluded white would have an action, he has immunized himself from a section 1981 or 1982 action. In response to the objection that this makes the sections too easy to evade, it can be argued that at least the sections put significant barriers in the path of one who seeks to do so. In addition, such evasive action would be financially impractical in the ordinary commercial setting where the protection of rights is most far-reaching and significant.

99. Iguored here, of course, are the legalities of placing such an advertisement. $C f$. Pittsburgh Press Co. v. Pittsburgh Comm'n on Human Relations, 413 U.S. 376 (1973) (upholding local ordinance which prohibited discrimination on the basis of race or sex iu advertising for employment opportunities).

100. McCrary v. Runyon, 515 F.2d 1082, 1087-88 (4th Cir.), cert. granted, 96 S. Ct. 354 (1975); Riley v. Adirondack S. School for Girls, 368 F. Supp. 392, 397-98 (M.D. Fla. 1973); cf. Tillman v. Wheaton-Haven Recreational Ass'n, 410 U.S. 431 (1973); Sullivan v. Little Huntmg Park, Inc., 396 U.S. 229 (1969) (status of a private club was denied when the sole selective criterion was race). Just as excluding blacks 
Thus, the "same right to contract" guaranteed by section one of the Civil Rights Act of 1866 is not intended to put legal compulsion behind a private offer. It comes into play only when an offeror or invitor refuses to contract with an individual solely because of his race. The key inquiry is to ascertain the class of potential contracting parties, and at that point to ask if both whites and nonwhites are treated equally. ${ }^{101}$

\section{Are There Constitutional Limitations to Section 1981?}

The courts and commentators have assumed that section 1981 is restricted in scope by the freedom of association and by an individual's right of privacy. ${ }^{102}$ In $\mathrm{McCrary}$, although the inajority found no violation of constitutional rights in its application of section 1981, the issues were seriously discussed. ${ }^{103}$ These constitutional considerations, lowever, do not confine the application of the statute when it is properly interpreted.

An independent "freedom of association" is a relatively recent development in constitutional law. ${ }^{104}$ The right is not expressly identified in either the national or state constitutions, ${ }^{105}$ and its constitutional underpinnings, ${ }^{106}$ as well as the scope of its protection, ${ }^{107}$ have not been

from membership does not make a private club, excluding blacks from an offer does not limit the class of possible acceptors in a way that avoids sections 1981 or 1982.

101. It should be stressed that the reading of the statute suggested in the text would not permit an evasion of its protection by the simple device of excluding some segment of the white population. For instance, a geographic limitation would not immunize the offeror from a section 1981 action, since those black persons who meet all other qualifications-including the geographical designation-could invoke the statute. Similarly, the express exclusion of some whites on the basis of financial or educational criteria would not protect against a section 1981 suit by a black who meets all the requirements. Such an argument was put forth in McCrary: "It is contended here . . . that $\$ 1981$ confers no right of action unless the contract denied the aggrieved person was open to all white people." 515 F.2d at 1087. The court rejected this argument, pointing out that within the qualified class "there were no other limitation[s] upon the admission of" any white applicant. Id. Thus, the Fourth Circuit's understanding of the scope of section 1981 is not at odds with that suggested in this Note.

102. See, e.g., McCrary v. Runyon, 515 F.2d 1082 (4th Cir.), cert. granted, 96 S. Ct. 354 (1975); Cornelius v. Benevolent Protective Order of Elks, 382 F. Supp. 1182 (D. Conn. 1974); Comment, Jones v. Alfred H. Mayer Co., supra note 10, at 476-79; Private Schools 1391-1400; 45 Miss. L.J. 246 (1974).

103. 515 F.2d at $1087-89$.

104. A constitutional freedom of association was first announced in NAACP v. Alabama, 357 U.S. 449, 460 (1958). The notion of a freedom to associate, however, is not so new. "The right of Americans freely to associate with whomever they choose is universally recognized as fundamental in a democratic society." D. Fellman, The Constitutional RIGHT of Association 34 (1963), citing Laski, Freedom of Association, in VI ENCYCLOPAEDIA of the SOCIAL SCIENCEs 447-50 (1931).

105. D. FELLMAN, supra note 104, at 3.

106. Id. ("The broader rights of association have developed in part, out of the right 
clearly articulated. Whether this constitutional freedom can be employed to protect the association of white children in a private school by denying to blacks the opportunity to join the association was the question before the $\mathrm{McCrary}$ court.

The dissent relied heavily on a primary/secondary distinction to determine when the freedom of association should override other interests. ${ }^{108}$ While primary relationships are "basically relationships between friends" cliaracterized by "intimate association," secondary relationships are "impersonal, highly formalized relations between people." ${ }^{08}$ To the dissent, the school situation involved a primary relationship and thus section 1981 could not be constitutionally applied. ${ }^{110}$ Leaving aside the fact that application of a "primary relationship" label to the facts of McCrary is highly questionable, the primary/secondary distinction still should not be seen as the ultimate or exclusive test for invoking the riglit of associational freedom over other legitimate interests. Although helpful as an imitial requirenent, it breaks down under even cursory analysis, for it is obvious that the state has the power to regulate even the niost primary of relationships. For example, a luusband and wife can be restrained from indulging in sexual activity in public. ${ }^{111}$ The primary/secondary distinction, then, does not afford definitive guidance even in those situations where the freedom of association and right to privacy can be legitinately applied.

Apart fron the question of primary or secondary relationship, the freedom of association cannot be legitinately utilized in a section 1981 action. It must be recalled that section 1981 applies only when race is the sole notive for discrimination. Althougl private racial discrimintion might be characterized as an exercise of the freedon to associate, sucl discrimination has never been accorded affirmative constitutional protections. ${ }^{112}$ When the government, through section 1981, seeks to

of assembly, and in part out of broader due process concepts."); Emerson, Freedom of Association and Freedom of Expression, 74 YALE L.J. 1, 2 (1964).

107. See note 115 infra.

108. 515 F.2d at 1095 (dissenting opinion).

109. Id., quoting Comment, Jones v. Alfred H. Mayer Co., supra note 10, at 478 . The original source of the distinction is found in Sengstock \& Sengstock, Discrimination: A Constitutional Dilemma, 9 WM. \& MARY L. REv. 59, 117 (1967).

110. 515 F.2d at 1095 (dissenting opmion).

111. See, e.g., Mich. Stat. ANn. \& $28.570(2)$ (1972); Wis. Stat. ANn. § 944.20(1) (1958).

112. Norwood v. Harrison, 413 U.S. 455,470 (1973). As previously noted, the Court in Norwood specifically mentioned in this context that even some private discrimination is subject to legislation, like section 1981, which is promulgated under the thirteenth amendment. Id. See also Tillman v. Wheaton-Haven Recreational Ass'n, 410 U.S. 431 (1973) (status as a private club denied when sole selection criterion was race); 
compel personal associations which are resisted solely on the basis of race, the constitutional right of association simply is not involved. ${ }^{113}$ Where the issue is not whether a group of people will be permitted to associate for a specified purpose, but whether they can exclude others from that association for whatever reason, the right being asserted is one of non-association. Such an asserted right inore appropriately falls under the rubric of privacy. ${ }^{11.4}$ As a result, the freedom of association may not be invoked as a bar to application of section $1981 . .^{115}$

Sullivan v. Little Hunting Park, Inc., 396 U.S. 229 (1969); McCrary v. Runyon, 515 F.2d 1082, $1087-88$ (4th Cir.), cert. granted, 96 S. Ct. 354 (1975) ("Among private schools, they are free to prefer one with a certain curriculum or dogma over others, but the school, while it may exclude applicants on the basis of neutral principles, may not exclude on the basis of race.").

113. But see Moose Lodge v. Irvis, 407 U.S. 163, 179-80 (1972) (Douglas, J., dissenting), quoted in McCrary v. Runyon, 515 F.2d 1082, 1095 (4th Cir. 1975) (Russell, Field, \& Widener, JJ., dissenting) ("The associational rights which our system honors permit all white, all black, all brown, and all yellow clubs to be formed . . . . Government may not tell a man or woman who his or her associates must be. The individual can be as selective as he desires.").

114. See Emerson, supra note 106, at 20-21.

115. The freedom of association has been apphed to political, social, economic, religious, recreational, and cultural groups. See generally C. Rice, Freedom of AssociaTION (1962); Note, Association, Privacy and the Private Club: The Constitutional Conflict, 5 HARv. Crv. Rights-Crv. LiB. L. Rev. 460 (1970). The freedom to associate has been linked to the first amendment freedom of expression. Norwood v. Harrison, 413 U.S. 455, $469-70$ (1973); Griswold v. Connecticut, 381 U.S. 479, 483 (1965); Bell v. Maryland, 378 U.S. 226, 313 (1964) (Goldberg, J., concurring).

It has been argued by at least one commentator that due to its compulsory nature, education falls outside the ambit of the freedom of association. In those cases where the freedom has been invoked, the members of the group of their own free will decided whether to join any group or no group. "The student, however, may not decide whether to go to school. The only voluntary decision the student may make, except for preschool education and education in excess of the amount required by law, is which school to attend." 42 U. CIN. L. Rev. 767, 770 (1973) (footnote omitted). There is at least some support for the proposition that the student has a constitutional right to make a free choice in this regard, for Evans v. Newton, 382 U.S. 296 (1966), speaks of "the right of the individual to pick his own asssociates so as to express his preferences and dislikes, and to fashion his private life by joining such clubs and groups as he chooses." Id. at 298. See also Is I98I the Answer? 1170 ("Although [discriminatory admission policies] allow white children to choose to associate only with other whites, they do not accommodate the choice of black children to associate freely with white children."). See generally Comment, Discrimination in Private Social Clubs: Freedom of Association and Right to Privacy, 1970 Duke L.J. 1181, 1208.

More to the point, however, is the reality that the child is not actually making an informed choice about which school to attend. "[W]hat are basically at issue here are not the associational rights of a student who desires colleagues of a certain color, but the rights of parents to be certain their children receive racially restricted education." Is 198I the Answer? 1170 (footnote omitted). See also King, Rebuilding the "Fallen House"-State Tuition Grants for Elementary and Secondary Education, 84 HaRv. L. Rev. 1057, 1078 (1971). See generally Private Groups 1458 (finds little support for a broad freedom of association concept); 11 HousroN L. REv. 691, 696-97 (1974) 
Similarly, the right of privacy has no relevance in a section 1981 action. The fact overlooked by those asserting such a limitation is that section 1981 does not force anyone to accept an offer. It operates only against an individual who has voluntarily initiated contractual relations with a personally unidentified group. ${ }^{116}$

The McCrary inajority gave the following hypothetical: "Should siblings combime to employ tutors for their children, they may exclude the rest of the world, for the rule of exclusivity bars the more distantly related and the unrelated regardless of race."117 Here the court focused on the fact that there was a nonracial reason for rejecting a section 1981 claim. But the rationale issue need not have been raised at all, for in the hypothetical the sibling school made no offer to educate others. ${ }^{118}$ The statute would not come to the aid of a nonwhite outsider who offered a sum of money for his child's admission into the school.

A common example thought to demonstrate the constitutional limits of section 1981 was given in Cornelius v. Benevolent Protective Order of Elks:119

[A] black man could not bring an action against a white woman alleging that she had refused to consider marrying him because of his race. Marriage is a contractual relationship but it is also one of the most private of relationships, and this privacy interest has constitutional dimensions.... There is, thus, a constitutional brake on section $1981 .{ }^{120}$

The error in this analysis is not that the right of privacy does not extend this far. The true error hes in alleging that section 1981 does. In the above situation, the man is the initiator, not the woman, and therefore section 1981 is inapplicable.

It can also be easily demonstrated from a practical standpoint that the right of privacy is not a constitutional restriction on section $1981 .^{121}$ It is clear that the right extends only to the most private and intimate of situations. ${ }^{122}$ Section 1981 does not come into play, however, unless

(freedom of association not a bar to section 1981 education action); 7 LoYOLA or L.A.L. REv. 634, 650 (1974) (freedom of association not a bar in education if not a bar in obscene films); 45 Mrss. L.J. 246 (1974) (calls for balancing of commercial and associational interests in education to see which predominates).

116. See notes 84-101 supra and accompanying text.

117. 515 F.2d at 1088-89.

118. Cf. Cook v. Advertiser Co., 458 F.2d 1119 (5th Cir. 1972); Kyles v. Calcasien

Parish Sheriff's Dep't, 395 F. Supp. 1307 (W.D. La. 1975).

119. 382 F. Supp. 1182 (D. Conn. 1974).

120. Id. at 1198, citing Griswold v. Connecticut, 381 U.S. 479 (1965).

121. This argument also applies in many situations to the freedom of association.

122. See Roe v. Wade, 410 U.S. 113 (1973); Doe v. Bolton, 410 U.S. 179 (1973);

Griswold v. Connecticut, 381 U.S. 479 (1965). 
the offeror or invitor initiates the contractual relationship without specifically identifying the offeree or invitee. ${ }^{123}$ In such a case the requisite intimacy and privacy are entirely lacking. The contracts involved in a 1981 action consequently will always be too commercial and involve too great a degree of publicity to be afforded constitutional protection. ${ }^{124}$

123. An offer or invitation to join a group can be made to an individual or group whose personal identity is wholly ascertained, partially ascertained, or unascertained. The simplest case is that of a single individual asked to join a group. If he alone is asked there can be no section 1981 discrimination since he is the sole member of the invited class. (It would be specious to argue that he would ever be denied adunission after such an explicit offer has been given. Even if this does occur, the reasons would undoubtedly be nonracial since that factor in this human equation is a constant.) The same reasoning pertains to a fully identified group of invitees. The point is that the offering group would not extend the offer to a black individual or group if they knew the identity of the class and had a discriminatory intent. In many situations, however, the offer is extended to a group which is not wholly identified. It is in this open-ended offer/invitation situation, where blacks meet all other qualifications of the class but are denied a contractual relationship solely because of their race, that section 1981 comes into operation. See text accompanying notes 84-101 supra. See also note 124 infra.

124. Perhaps an example would clarify this point. Group A is a small group of close friends who meet together at B's invitation every week to swim in B's pool. (It is clear at this point that no one cau legally force his entrance into this group.) But occasionally a inember of the group will move to another town. At that point in time B decides to whom among his acquaintances he will offer the vacant place. In such a case the class of offerees is made up of only one person. If he happens to be nonwhite, it is obvious that no section 1981 action will occur since his acceptance of the offer of membership will never be rejected. (Even more basic, section 1981 will not apply to this situation because there is no contractual relationship since $B$ receives no consideration for his generosity. See Cook v. Advertiser Co., 458 F.2d 1119 (5th Cir. 1972); Kyles v. Calcasien Parish Sheriff's Dep't, 395 F. Supp. 1307, 1310-11 (W.D. La. 1975)).

On the other hand, a different situation presents itself if, after member $X$ departs, $B$ decides to fill the vacant position by advertising in the local newspaper that upon receipt of $\$ 500$ any male in Town $T$ may join the swimming group. In that case, assuming the advertising constitutes an offer, the class of offerees includes all male members of Town T. Within that class, section 1981 guarantees that whites and nonwhites will be treated equally. But $B$ has no idea of the ultimate acceptor's personal identity at the time he inakes the offer. Such a transaction is too commercial to be afforded constitutional protection as a matter of "privacy." As stated in $\mathrm{McCrary}$, "[w]hen a school holds itself open to the public, ... . there is no perceived privacy of the sort that has been given constitutional protection." 515 F.2d at 1088. See also Cornelius v. Benevolent Protective Order of Elks, 382 F. Supp. 1182, 1204 (D. Conn. 1974) ("To have their privacy protected, clubs must function as extensions of members' homes and not as extensions of their businesses. Racial prejudice will not be permitted to infect channels of commerce under the guise of 'privacy." "). The intriguing practical point is that section 1981 will almost never be used except in situations where an offer has been held open to the public. Holding an offer open to the public means extending it to those whom one has not personally approached. No right of privacy attaches to such a relationship.

The Civil Rights Act of 1964, 42 U.S.C. $\$ \S 2000$ a et seq. (1970), provides an exemption for private clubs:

The provisions of this subchapter shall not apply to a private club or 
In summary, section 1981 extends to all private contracts but only comes into play when an individual voluntarily initiates contractual relations, then reneges at consummation solely on the basis of race. ${ }^{\mathbf{1 2 5}}$ When the statute is imterpreted in this manner, section 1981 actions are not restrained by the right of privacy or freedom of association. ${ }^{126}$

other establishment not in fact open to the public, except to the extent that the facilities of such establishment are made available to the customers or patrons of an establishment within the scope of subsection (b) of this section. Id. § $2000 \mathrm{a}(\mathrm{e})$.

In liglit of the saving clause, id. $\$ 2000 \mathrm{a}-6(\mathrm{~b})$, it seems probable that the private club exception would also apply to section 1981 actions. Cf. United States v. Johnson, 390 U.S. 563, 566 (1967). Some courts liave so lield. See Cornelius v. Benevolent Protective Order of Elks, 382 F. Supp. 1182 (D. Conn. 1974); Solomon v. Miami Woinan's Club, 359 F. Supp. 41 (S.D. Fla. 1973); Simms v. Order of Commercial Travelers, 343 F. Supp. 112, 113-14 (D. Mass. 1972). It is also clear, however, that race alone is not a valid selective factor. A club which excludes only blacks does not qualify for the exemption. See Tillman v. Wheaton-Haven Recreation Ass'n, 410 U.S. 431, 438 (1973); Sullivan v. Little Hunting Park, Inc., 396 U.S. 229, 236 (1969); Nesmith v. Y.M.C.A., 397 F.2d 96, 102 (4th Cir. 1968); Solomon v. Miami Wolnan's Club, 359 F. Supp. 41, 44 (S.D. Fla. 1973). See generally Note, Private Clubs: The Right to Discriminate in Admissions Policies, 34 U. PITr. L. REv. 447 (1973); Private Groups 1452-55.

The purported conflict between section 1981 and private clubs is nore inagined than real. Although it has beeu leld that "[g]overnment nuay not tell a man or woman who his or lier associates must be," Gilmore v. Montgomery, 417 U.S. 556, 575 (1974), quoting Moose Lodge v. Irvis, 407 U.S. 163, 180 (1972) (Douglas, J., dissenting), section 1981 does not attempt to force a contract on anyone or any group. It does not mandate association. Since the section does not sweep so broadly, there is no conflict with the privacy of private clubs.

125. It is true that in the example given in note 124 supra there is room for manipulation in order to exclude blacks fron membership. The courts have not been fooled in the past, however. See, e.g., Tillman v. Wheaton-Haven Recreation Ass'n, 410 U.S. 431 (1973); Olzman v. Lake Hills Swim Club, Inc., 495 F.2d 1333 (2d Cir. 1974). In addition courts have delineated stringent requirements which a private club must meet. Factors include the selectiveness of the group in the admission of members, the existence of formal membership procedures, the membership control over internal governance, the history of the organization, the use of facilities by nonmembers, the substantiality of dues, the club's decision coucerning advertising, and the predominance of the profit motive. See Cornelius v. Benevolent Protective Order of Elks, 382 F. Supp. 1182, 1203 (D. Conn. 1974). See generally Daniel v. Paul, 395 U.S. 298 (1969); Stout v. Y.M.C.A., 404 F.2d 687 (5th Cir. 1968).

It should be remembered that section 1981's "same right to make and enforce contracts" does not apply unless there is an enforceable contractual relationship present. See Cook v. Advertiser Co., 458 F.2d 1119 (5th Cir. 1972); Player v. Dep't of Pensions \& Security, 400 F. Supp. 249, 265 (M.D. Ala. 1975).

126. Contract law reflects to a large extent the privacy notions of the populace. Although breach of promise to marry actions were permitted a century ago when a marriage contract was often an arms-length transaction, today such actions are prohibited by statute in many states. See 12 AM. Jur. 2D Breach of Promise $\$ \$ 18-20$ (1964); Annot., 73 A.L.R.2D 553 (1960). This undoubtedly stems in large part from the fact that today the marriage contract is considered a much more intimate and personal choice. In other words, it is a much less commercial transaction in the modern world. 


\section{Prognostication: ExPANSION OF THE SECTION 1981 REMEDy IN EdUCATION}

Undoubtedly there were those in 1954 who believed that the Supreme Court's decision in Brown v. Board of Education ${ }^{127}$ marked the end of the black man's long struggle for equality in education. If so, they were to be sorely disappointed. Brown, however, does provide an effective weapon with which to fight the battle in the public schools. It now appears that the Supreme Court will allow the battle to be acted out on an additional front. The key question remaining, therefore, is whether the provision of section 1981 that nonwhites have the same right as white citizens to make contracts guarantees equal education as well as equal admissions.

Following Brown, numerous attempts were made to circumvent that decision's clear intent to provide equal education for blacks. Even open resistance was attempted. ${ }^{128}$ More commonly the "all deliberate speed" requirement of Brown II ${ }^{129}$ was stretched almost beyond recogmition. ${ }^{130}$ Even after blacks entered the schoolhouse door, however, they encountered obstacles to an equal education. ${ }^{131}$ Examples included the maintenance of segregated classes within outwardly integrated schools, ${ }^{132}$ the use of "ability groupings,"133 and improper utilization of I. Q. and achievement tests. ${ }^{134}$

127. 347 U.S. 483 (1954).

128. Cooper v. Aaron, 358 U.S. 1 (1958) (National Guard units kept black students from entering public high school because of public hostility). See also Bush v. School Bd., 188 F. Supp. 916 (E.D. La.), aff'd, 365 U.S. 569 (1961) (state "interposition statute" declared invalid).

129. 349 U.S. 294 (1955).

130. See Alexander v. Board of Educ., 396 U.S. 19 (1969); Green v. County School Bd., 391 U.S. 430 (1968); Bradley v. School Bd., 382 U.S. 103 (1965); Griffin v. County School Bd., 377 U.S. 218 (1964); Bell v. Rippy, 146 F. Supp. 485 (N.D. Tex. 1956), rev'd sub nom. Borders v. Rippy, 247 F.2d 268 (5th Cir. 1957). See also Holt v. Board of Educ., 265 F.2d 95 (4th Cir.), cert. denied, 361 U.S. 818 (1959); Covington v. Edwards, 264 F.2d 780 (4th Cir.), cert. denied, 361 U.S. 840 (1959); Carson v. Warlick, 238 F.2d 724 (4th Cir.), cert. denied, 353 U.S. 910 (1957) (demonstrates many of procedural and administrative hurdles placed in way of integration); Kelley v. Board of Educ., 270 F.2d 209 (6th Cir.), cert. denied, 361 U.S. 924 (1959); Slade v. Board of Educ., 252 F.2d 291 (4th Cir.), cert. denied, 357 U.S. 906 (1958) (demonstrates the gradual, grade-at-a-time integration process). See generally R. SAYLES, The WARREN Court: A Critical ANaLYsis 46 et seq. (1969).

131. See generally D. BeLL, RACE, RACISM AND AMERICAN LAW 471-97 (1973).

132. See Jackson v. Marvell School Dist. No. 22, 425 F.2d 211 (8th Cir. 1970).

133. See Moses v. Washington Parish School Bd., 330 F. Supp. 1340 (E.D. La. 1971).

134. See Hobson v. Hansen, 269 F. Supp. 410 (D.D.C. 1967), aff'd sub nom. Smuck v. Hobson, 408 F.2d 175 (D.C. Cir. 1969) (system of "tracking" students struck down). But cf. Pettit v. Board of Educ., 184 F. Supp. 452 (D. Md. 1960). 
Does section 1981, then, provide only a hollow right to contract in the education field by taking a black child to the schoolhouse door but not accompanying him inside? The answer is very probably "no." Section 1981 gives the same or equal right to contract to a black man that a white man enjoys. The black inan has not just contracted with a private school for the admission of his child. He has contracted for that child's education. If that child receives discriminatory treatment once inside the schoolhouse, the parent is not receiving the same value for his investment that a white man is. ${ }^{135}$ Simply put, he is not receiving the same right to contract.

There is authority for this position in the case law. In Jones the Court spoke im strong words, stating that the thirteenth amendment is not a "inere paper guarantee" and that it assures that "a dollar in the hands of a Negro will purchase the same thing as a dollar in the hands of a white inan."136

This language was taken quite seriously in both Sullivan and Tillman. In both cases the property rights of the plaintiffs were seen to be diluted because otherwise automatic membership options in recreational facilities were denied thein solely on account of their race. A unanimous Court elaborated in Tillman:

When an organization links membership benefits to residency in a narrow geographical area, that decision infuses those benefits into the bundle of rights for which an individual pays when buying or leasing within the area. The mandate of . . \& 1982 then operates to guarantee a nonwhite resident . . . the same rights as are enjoyed by a white resident. ${ }^{137}$

135. As a matter of law such discriminatory education is inferior. See Brown v. Board of Educ., 347 U.S. 483 (1954); Hobson v. Hansen, 269 F. Supp. 401 (D.D.C. 1967), aff'd sub nom. Smuck v. Hobson, 408 F.2d 175 (D.C. Cir. 1969).

In the district court in the McCrary litigation the Southern Independent School Association, as intervenor, proffered testimony to show that "segregation is desirable in education in light of the performance of these schools and current scientific theory ...." Gonzales v. Fairfax-Brewster School, Inc., 363 F. Supp. 1200, 1204 (E.D. Va. 1973), aff'd sub nom. McCrary v. Runyon, 515 F.2d 1082 (4th Cir.), cert. granted, 96 S. Ct. 354 (1975). The court deemed such testimony legally irrelevant due to its rejection in Brown. But see Bell v. Rippy, 146 F. Supp. 485 (N.D. Tex. 1956), rev'd sub nom. Borders v. Rippy, 247 F.2d 268 (5th Cir. 1957).

136. The following is the full text of the passage:

Negro citizens, North and South, who saw in the Thirteenth Amendment a promise of freedom-freedom to "go and come at pleasure" and to "buy and sell when they please"-would be left with "a mere paper guarantee" if Congress were powerless to assure that a dollar in the hands of a Negro will purchase the same thing as a dollar in the hands of a white man. At the very least, the freedoin that Congress is empowered to secure under the Thirteenth Amendment includes the freedom to buy whatever a white man can buy, the right to live wherever a white man can live. If Congress cannot say that being a free man means at least this much, then the Thirteenth Amendment made a promise the Nation cannot keep. 392 U.S. at 443 (citations omitted).

137. 410 U.S. at 437. 
If membership options in a pool are part of the "bundle of rights" protected when one buys a house, it seems clear that an equal education is part of the "bundle of rights" contracted for when one places a child in private school. Many individuals when purchasing a house are totally indifferent to such recreation options and it would be the rare case indeed when it was a controlling factor. In the school situation, on the other hand, a parent always expects his child to receive equal educational opportumities and facilities. He only enrolls his child in a private school if he anticipates more benefits than are offered by the public schools of the area. The quality of education is not only part of the bundle of rights for which he is contracting, it is the whole bundle.

It seems very likely that there will be redress in the private school situation under section 1981 for the same types of evasions, and even good-intentioned procedures, which have caused discriminatory and unequal education in the public schools. Since segregated classes, like segregated school systems, are inherently unequal, ${ }^{138}$ a parent of a black child otherwise would not be receiving the same right to contract as the parent of a white child. Section 1981 assures that "a dollar in the hands of a Negro will purchase the same thing as a dollar in the hands of a white man." ${ }^{33}$ Nowhere is this more important than in education. ${ }^{140}$

138. See Brown v. Board of Educ., 347 U.S. 483 (1954); Jackson v. Marvell School Dist. No. 22, 425 F.2d 211 (8th Cir. 1970).

139. Jones v. Alfred H. Mayer Co., 392 U.S. 409, 443 (1968).

140. The courts in applying section 1981 to education may rely in large part on analogous case law. With respect to subtle discrimination in the classroom, recourse can be had to the decisions following Brown. See notes 128-135 supra. As to the burden of proof in such action, the courts may generally look to the procedures adopted in section 1982 actions, see Williams v. Matthews Co., 499 F.2d 819 (8th Cir.), cert. denied, 419 U.S. 1021 (1974); Olzman v. Lake Hills Swim Club, Inc., 495 F.2d 1333, 134042 (2d Cir. 1974); Note, Racial Discrimination in Public Housing, Rights and Remedies, 41 U. CHI. L. Rev. 582 (1974), and section 1981 employment cases, see Larson, The Development of Section 1981 as a Remedy for Racial Discrimination in Private Employment, 7 Harv. Crv. Rights-Civ. LiB. L. Rev. 56 (1972). See also Brown, Givelber \& Subrin, supra note 97; Note, Beyond the Prima Facie Case in Employment Discrimination Law: Statistical Proof and Rebuttal, 89 HARv. L. REv. 387 (1975).

Another commentator suggests a two-step analysis. First, does the defendant have a history of racial discrimination? Second, are there facts indicating racial discrimination against this particular plaintiff? 42 U. CIN. L. Rev. 767 (1973). See also Is 1981 the Answer? 1174-75 (argues that where there is a history of rejecting all or substantially all blacks, the burden should be on the school to disprove discrimination, this being particularly crucial when subjective reasons are given for the rejection); Private Groups 1474 (suggesting that past adinissions criteria should be frozen so that subjective factors cannot be used as a screen for discrimination); cf. Fiss, Gaston County $v$. United States: Fruition of the Freezing Principle, 1969 SUP. CT. REv. 379. 


\section{CONCLUSION}

The increasing importance of the Civil Rights Act of 1866 is evidenced by its ever-extending reach into private action. This extension is not without limitation, however, for while section 1981 does indeed reach even to private educational activity, the statute is applicable only when a nonwhite otherwise qualifies to enter into a contractual relationslip which has been aborted solely because of the eleinent of race. It must also be remembered that section 1981 aids only those who are attempting to accept an open-ended offer or invitation and wlio constitute part of the qualified class to whom it has been extended. On the other hand, a proper application of section 1981 is not limited by the constitutional issues of associational freedom and the right to privacy.

The impact of $\mathrm{McCrary}$ on private education cannot yet be measured. Each action brought under section 1981 will require careful analysis of school policy, both past and present, and the child's individual qualifications. It is clear, lowever, that $M c C$ rary requires consideration of each child on his inerits as a person and not on the color of his skin. ${ }^{141}$ This badge and incident of slavery has rightly been put to rest.

141. See Borders v. Rippy, 247 F.2d 268, 271 (5th Cir. 1957) (fourteeuth ameudment): "Pupils may, of course, be separated according to their degree of advancement or retardation, their ability to learn, on account of their health, or for any other legitimate reason, but each child is eutitled to be treated as an individual without regard to his race or color." 
